\title{
Strategi Komunikasi Humas Universitas Tarumanagara selama Pandemi Covid-19
}

\author{
Shinta Darmawaty ${ }^{1}$, Septia Winduwati ${ }^{2 *}$ \\ ${ }^{1}$ Fakultas Ilmu Komunikasi, Universitas Tarumanagara \\ Email: shinta.915170061@stu.untar.ac.id \\ ${ }^{2}$ Fakultas Ilmu Komunikasi, Universitas Tarumanagara* \\ Email: septiaw@fikom.stu.untar.ac.id
}

Masuk tanggal : 15-12-2021, revisi tanggal : 06-01-2022, diterima untuk diterbitkan tanggal : 16-01-2022

\begin{abstract}
Public Relations in University has a core role especially during a pandemic like now. The purpose of this research is to find out how the PR communication strategy of a private university, in this case, Tarumanagara University during the Covid-19 pandemic. This study uses a theoretical foundation in the form of communication, communication strategies, internal and external stakeholders, and public relations of educational institutions, with a qualitative research approach, a case study method which is one of the research strategies to develop an in-depth analysis with the subject matter of the communication strategies applied by University Public Relations. Tarumanagara during the Covid-19 pandemic. During the pandemic, Public Relations of Tarumanagara University delivered messages using an informal message delivery method, and the messages arranged were also adjusted depending on who the audience was, to find out who the audience was Public Relations of Tarumanagara University divided into two types of audiences, such as internal audiences consisting of Lecturers, employees and students, as well as external audiences consisting of the Government, the media, the surrounding community (community), alumni, and the general public. Social and digital media have become the most reliable means of communication during the Covid-19 pandemic.
\end{abstract}

Keywords: covid-19, communication strategy, public relations, university

\begin{abstract}
Abstrak
Humas Perguruan Tinggi Swasta (PTS) terlebih lagi pada saat pandemi. Tujuan dari penelitian ini adalah untuk untuk mengetahui bagaimana strategi komunikasi Humas Perguruan Tinggi Swasta dalam hal ini, Universitas Tarumanagara selama pandemi Covid-19. Penelitian ini menggunakan landasan teoritik berupa komunikasi, strategi komunikasi, stakeholders internal dan eksternal, dan humas lembaga pendidikan, dengan pendekatan penelitian kualitatif, metode studi kasus yang dimana merupakan salah satu strategi penelitian untuk mengembangkan analisis mendalam dengan pokok masalah bagiamana startegi komunikasi yang diterapkan humas Universitas Tarumanagara selama pandemi Covid-19. Selama pandemi, humas Untar menyampaikan pesan dengan menggunakan metode penyampaian pesan yang iformatif, dan pesan yang disusun juga disesuaikan dengan tergantung siapa yang menjadi khalayaknya, untuk mengetahui siapa khalayakHumas Untar membagi ke dalam dua macam khalayak, seperti khalayak internal yang terdiri dari, Dosen, karyawan dan Mahasiswa, serta khalayak eksternal yang terdiri dari pemerintah, media, masyarakat sekitar (komunitas), alumni, dan masyarakat umum. Media sosial dan digital menjadi alat komunikasi yang paling diandalkan selama pandemi Covid-19.
\end{abstract}

Kata Kunci: covid-19, humas, strategi komunikasi, universitas 


\section{Pendahuluan}

Di Indonesia pendidikan menjadi salah satu sektor yang dihimbau untuk tidak melakukan kegiatan belajar-mengajar secara tatap muka selama pandemi Covid-19, sehingga harus dilakukan secara daring, terlebih lagi, di dalam perguruan tinggi terdapat kegiatan administrasi dan perkantoran seperti di Universitas Tarumanagara (Untar).

Selama masa pandemi Covid-19 Untar telah menerapkan kuliah daring dan Work From Home (WFH) kepada mahasiswa dan karyawannya. Untar merupakan organisasi nirlaba yang menurut Connolly dan Kelly organisasi nirlaba merupakan sebuah organisasi yang tidak mendapatkan laba dan jika memiliki pendapatan lebih akan digunakan kembali untuk mencapai tujuan organisasi tersebut, dalam (Siskawati et al., 2015: 30).

Dalam penelitian yang dilakukan Luqman (2013: 3) humas harus bersifat fleksibel sehingga dapat merespon dengan cepat peristiwa yang sedang terjadi dengan strategi komunikasi yang sudah direncakana sebelumnya. Maka dari itu karena pandemi Covid-19 seperti ini humas perguruan tinggi harus bersifat fleksibel sehingga dapat melakukan inovasi dalam membuat strategi komunikasi agar tetap dapat menjalankan komunikasi yang baik dengan publik internal dan eksternal.

Maka dari itu karena pandemi Covid-19 humas perguruan tinggi swasta harus mampu memenuhi kebutuhan pesan dan informasi untuk setiap publik internal dan eksternal organisasi. Humas Untar diharapakan mampu menggerakkan komunikasi internal dan eksternal yang mungkin akan memiliki rintangan tersendiri.

Strategi komunikasi yang digunakan humas harus tetap efektif dan informatif sehingga dapat membantu jalannya komunikasi secepat mungkin, dalam memenuhi kebutuhan informasi terbaru serta dimanfaatkan untuk menghindari arus informasi yang simpang siur dan tidak jelas di antara publiknya

Rumusan masalah penelitian ini adalah bagaimana strategi komunikasi humas Universitas Tarumanagara selama pandemi Covid-19? Sedangan tujuan penelitian ini adalah mengetahui bagaimana strategi komunikasi Humas Universitas Tarumanagara selama pandemi Covid-19.

\section{Komunikasi}

Komunikasi merupakan sarana bagi seseorang untuk dapat mengekspresikan dirinya agar dapat mempersuasi orang lain, selain itu komunikasi juga dapat digunakan untuk membangun dan mempertahankan relasi dengan orang lain dan dengan komunikasi seseorang dapat menyampaikan keinginan dan kebutuhannya kepada orang lain, dalam (Liliweri 2011: 35). Carl I Hovland mengatakan bahwa adanya komunikator yang memberikan rangsangan, untuk mempersuasi komunikan ke arah tingkag laku yang diinginkan komunikator (Mulyana, 2010: 68-69).

Sedangkan Eni Kardi Wiyati mengatakan bahwa komunikasi merupakan suatu proses penyampaian pesan yang ingin disampaikan oleh komunikator kepada komunikan, baik dalam bentuk penyampaian emosi, informatif ataupun pikiran (Budianto, 2011: 384).

\section{Strategi Komunikasi}

Effendy dalam (Tadarusman, 2013: 31) mendefinisikan bahwa stategi komunikasi merupakan bagian dari perencanaan suatu program komunikasi yang bertujuan untuk pencapaian tujuan, sehingga dalam prosesnya harus merencanakan 
sedetail mungkin untuk mempersiapkan segala perubahan yang dapat terjadi. Sedangkan Middleton dalam (Wijaya, 2015: 57) mengatakan bahwa strategi komunikasi merupakan suatu kombinasi yang baik dari semua elemen komunikasi yang sengaja disusun untuk pencapaian tujuan yang maksimal.

Pace dan kawan-kawan (dalam Effendy, 2011: 32) mengatakan bahwa strategi komunikasi memiliki tiga tujuan utama, sebagai berikut:

a. To Secure Understanding: komunikan mengerti isi pesan yang dimaksud.

b. To Establishes Acceptance: memberikan pembinaan kepada komunikan setelah pesan diterima.

c. To Motivation Action: untuk memotivasi aktivitas dalam organisasi.

Anwar Arifin dalam (Tadarusman, 2013: 31) mengatakan bahwa dalam penyusunan strategi komunikasi memiliki lima faktor yang perlu diperhatikan, yaitu berupa: (a). Mengenal Khalayak; (b). menentukan pesan; (c). menetapkan metode; (d). seleksi dan penggunaan media; (e). faktor pendukung dan penghambat komunikasi.

Kreitner dalam (Tadarusman, 2013: 31) memberikan empat macam hambatan yang dapat mengganggu jalannya komunikasi, sebagai berikut:

a. Hambatan dalam proses penyampaian

b. Hambatan secara fisik

c. Hambatan semantik

d. Hambatan sosial

\section{Stakeholders}

Guth dan Marsh (dalam Estaswara, 2012: 4) mengatakan bahwa stakeholders merupakan sekelompok publik yang memiliki kepentingan dalam sebuah organisasi/perusahaan. Menurut Estaswara tidak ada perusahaan atau organisasi yang dapat menacapai tujuannya tanpa berhubungan baik dengan stakeholders (Estaswara, 2012: 4-5).

a. Stakeholders internal merupakan publik yang memiliki kepentingan di dalam sebuah organisasi atau perusahaan seperti, tenaga administrasi, tenaga pendidik, karyawan, dan mahasiswa (Estaswara, 2012: 77).

b. Stakeholders eksternal merupakan pemangku kepentingan yang berada di luar organisasi, seperti, calom mahasiswa, alumni, Pemerintah daerah, masyarakat yang tinggal di sekitar organisasi, media serta masyarakat luas (Estaswara, 2012: 77).

\section{Public Relations}

Menurut Jefkins yang diambil dari (Juhji, dkk. 2020: 5) bahwa memelihara dan mempertahankan niat baik (good will) serta menciptakan sikap memahami antara organisasi dan publiknya merupakan usaha yang telah direncanakan oleh humas.

Dalam upaya menciptakan citra intitusi pendidikan yang positif, Humas dalam lembaga pendidikan memiliki empat peranan didalamnya, sebagai berikut (Juhji, dkk. 2020: 10): (a). Penghubung; (b). Pengkomunikasi; (c). Pendukung; (d). Publikator. Humas lembaga pendidikan khususnya pada perguruan tinggi juga memiliki fungsi menurut Nasution (dalam Setyanto dan Anggarina, 2015: 3) humas memiliki fungsi korektif dan fungsi konstruktif. 


\section{Metode Penelitian}

Patilima (2011: 2-3) mengatakan bahwa penelitian kualitatif pada umumnya dimanfaatkan untuk mengindentifikasi dan menganalisis masalah sosial yang terjadi di lingkungan masyarakat, yang mana didalamnya menuangkan informasi yang diberikan oleh objek penelitian yang bersangkutan secara lengkap. Pada penelitian ini, peneliti memilih menggunakan metode penelitian studi kasus. Karena menurut Sugiyono (2010: 3) metodologi penelitian studi kasus digunakan oleh peneliti untuk memperoleh data sesuai kebutuhan.

Teknik pengumpulan data wawancara dan studi dokumentasi, Moleong (2010: 186) mengartikan wawancara sebagai komunikasi yang terjalin antara peneliti dengan objek penelitian yang mengandung maksud dan tujuan tertentu. Sedangkan Studi dokumentasi menurut Sugiyono (2016: 240) proses pengumpulan gambar, tulisan masa lalu atau masa kini, serta karya-karya bersejarah. Narasumber dalam penelitian ini merupakan Kepala Humas Untar, Paula T. Anggarina yang paham terkait strategi komunikasi yang digunakan selama pandemi Covid-19 dan dokumentasi yang dilakukan oleh penulis dilakukan dengan mengkaji media sosial milik Universitas Tarumanagara dalam menjalankan tugasnya. Teknik analisis deskriptif menurut Miles dan Huberman seperti yang dikutip Sugiyono (2019: 321) diterapkan melalui 3 alur, yaitu: Reduksi data, penyajian data, dan penarikan kesimpulan. Menurut Norman K Denkin triangulasi memiliki empat jeni, yaitu, triangulasi antar peneliti, triangulasi metode, triangulasi sumber data, dan triangulasi teori. Dalam penelitian ini, penulis menggunakan triangulasi sumber data dan triangulasi teori.

\section{Hasil Temuan dan Diskusi}

Effendy dalam (Tadarusman, 2013: 31) mendefinisikan bahwa stategi komunikasi merupakan bagian dari perencanaan suatu program komunikasi yang bertujuan untuk pencapaian tujuan, sehingga dalam prosesnya harus merencanakan sedetail mungkin untuk mempersiapkan segala perubahan yang dapat terjadi. Pada tanggal 1 Desember 2020 penulis melakukan wawancara dengan Kepala Humas Universitas Tarumanagara, Paula T. Anggarina mengenai strategi komunikasi apa yang digunakan selama pandemi Covid-19.

Penulis menemukan bahwa strategi komunikasi yang digunakan oleh Humas Universitas Tarumanagara selama pandemi Covid-19 adalah komunikasi daring kepada publik internal dan eksternal, Kepala Humas Universitas Tarumanagara Paula T. Anggarina menjelaskan bahwa selama pandemi Covid-19 ini pola kerja tentu berubah, karena semua kegiatan harus dilakukan secara daring sehingga Humas Untar harus mampu menyesuaikan dengan kebiasaan baru tersebut.

Humas Universitas Tarumanagara mengimplementasikan komunikasi daring yang sebelumnya sudah direncanakan sematang dan sedetail mungin mengenai cara kerja komunikasi daring, hal tersebut bertujuan untuk mencegah terjadinya penularan virus Covid-19 di lingkungan internal Universitas Tarumanagara.

Pace, dkk. (dalam Effendy, 2011: 32) mengatakan bahwa strategi komunikasi memiliki tiga tujuan utama, dari hasil wawancara yang penulis lakukan, penulis menyimpulkan tujuan Humas Untar melakukan komunikasi, sebagai berikut: 
a. To Secure Understanding: komunikan mengerti isi pesan yang dimaksud. Dimana dalam hal ini Humas Untar ingin memastikan bahwa komunikan mengerti dengan pesan yang disampaikan secara daring.

b. To Establishes Acceptance: memberikan pembinaan kepada komunikan setelah pesan diterima. Karena masih ada publik internal seperti karyawan yang kurang memahami penggunaan platform video conference maka dari itu Humas Untar bekerja sama dengan unit lain untuk memberikan pembinaan kepada pihak internal agar dapat menggunakan platform video conference sebagai alat komunikasi yang akan banyak digunakan selama pandemi Covid19.

c. To Motivation Action: untuk memotivasi aktivitas dalam organisasi. Dengan diberikan pembinaan maka dari itu karyawan memiliki motivasi untuk bekerja dari rumah ditengah pandemi Covid-19.

Penyusunan strategi komunikasi memiliki empat faktor Anwar Arifin (dalam Tadarusman, 2013: 31), yaitu:

a. Mengenal khalayak

Untuk merencanakan sebuah strategi komunikasi, komunikator harus mengenal siapa khalayaknya, agar rancangan strategi komunikasi yang dibuat dapat tepat dan sesuai dengan sasaran yang dituju. Humas Universitas Tarumanagara membedakan khalayaknya menjadi dua yaitu khalayak internal dan khalayak eksternal, yang dimana khalayak internal terdiri dari Dosen, Mahasiswa, dan karyawan. Serta khalayak eksternal yang dibedakan menjadi masyarakat umum, media, Pemerintah, masyarakat sekitar atau komunitas, dan alumni. Dalam wawancara yang penulis lakukan dengan Firman Kurniawan, beliau mengatakan bahwa sebelum menyampaikan pesan, komunikator harus mengetahui dan memahami bagaimana karakteristik dari komunikan itu sendiri. Sehingga dapat menenukan pesan yang disampaikan

b. Menentukan Pesan

Dalam tahap ini, tema dan materi yang ingin disampaikan merupakan tahapan penting, karena penyusunan tema dan materi harus mampu membangun perhatian khalayak. Dalam hal ini humas membangun komunikasi dengan semua jenis khalayaknya sehingga pesan yang dibuat harus dapat disesuaikan tergantung siapa khalayak yang akan menerima pesan. Firman Kurniawan juga mengatakan bahwa dalam menentukan pesan, penting untuk melihat arah interest komunikan ke arah mana, jika komunikan cenderung tertarik kepada audio visual, maka harus disiapkan materi-materi dalam bentuk video yang menarik, atau jika komunikan lebih tertarik pada teks maka sediakan link bacaan-bacaan yang sekiranya dapat menarik perhatian khalayaknya.

c. Menetapkan Metode

Humas Universitas Tarumanagara menggunakan metode penyampaian pesan yang informatif. Firman Kurniawan juga mengatakan bahwa sebaiknya PTS memastikan menginformasikan kepada khalayak seperti calon mahasiswa bahwa dengan dilakukannya komunikasi daring tidak akan mengganggu jalannya perkuliahan daring serta menyampaikan jika kondisi sudah kembali seperti semula, maka semua kegiatan akan kembali seperti semula.

d. Seleksi dan Penggunaan Media

Dalam hal ini Humas Universitas Tarumanagara menjangkau khalayak internal dan eksternalnya dengan memanfaatkan media sosial seperti Facebook, Instagram, Twitter, Youtube, dan Website resmi institusi, MS. Teams, Zoom, 
WhatsApp, dan Line. Dari hasil wawancara penulis dengan Firman Kurniawan berpendapat bahwa kampus yang unggul merupakan kampus yang mampu beradaptasi dengan teknologi baru seperti yang sudah dilakukan Untar dalam menjangkau khalayaknya.

Humas lembaga pendidikan khususnya pada perguruan tinggi juga memiliki dua fungsi menurut Nasution (dalam Setyanto dan Anggarina, 2015: 3), yaitu fungsi korektif dan fungsi konstruktif, dari hasil wawancara penulis dengan Kepala Humas Universitas Tarumanagara, Paula T. Anggarina menemukan bahwa Humas Untar memegang fungsi konstruktif.

Menurut Nasution yang dimaksudkan sebagai fungsi konstruktif adalah humas diharapkan dapat membantu perguruan tinggi untuk memecahkan masalah sehingga dapat diterima oleh khalayak, begitu pula dengan kebijakan yang dikeluarkan oleh perguruan tinggi sehingga dapat diterima oleh seluruh pihak internal.

Dalam hal ini, Humas Universitas Tarumanagara memegang fungsi konstruktif karena Humas Universitas Tarumanagara bekerja sama dengan unit lain untuk memberikan pelatihan kepada pihak internal yang tidak menguasai komunikasi daring agar dapat menggunakan aplikasi MS. Teams yang akan digunakan sebagai alat komunikasi selama masa pandemi Covid-19. Dalam wawancara Kepala Humas Universitas Tarumanagara, Paula T. Anggarina juga mengatakan bahwa peranan humas dalam lingkungan Universitas selain memberikan informasi juga menerima masukan, penulis menemukan dari akun Instagram @untarjakarta bahwa selama pandemi Covid-19 Humas Universitas Tarumanagara telah menerima banyak masukan dan saran dari mahasiswa Universitas Tarumanagara yang disampaikan melalui email humas@untar.ac.id yang dimana saran dan masukan tersebut direspon positif oleh Humas Universitas Tarumanagara.

Kreitner dalam (Tadarusman, 2013: 31) memberikan empat macam hambatan yang dapat mengganggu jalannya komunikasi, yaitu: hambatan dalam proses penyampaian, hambatan secara fisik, hambatan semantik, dan hambatan Psiko-sosial. Dalam hal ini, hambatan yang dialami oleh Kepala Humas Universitas Tarumanagara yang penulis temukan adalah hambatan secara fisik dan hambatan dalam proses penyampaian.

Dari hasil wawancara penulis oleh Kepala Humas Universitas Tarumanagara, hambatan yang dirasakan selama menjalankan komunikasi daring adalah hambatan teknis, karena sinyal yang tidak stabil terlebih lagi jaringan keberadaan khalayaknya berbeda-beda karena tidak semua tempat memiliki kondisi jaringan yang sama, sehingga keadaan tersebut menghambat jalannya komunikasi dengan khalayak. Dalam hal ini, Firman Kurniawan mengatakan bahwa untuk mengatasi hal ini bisa saja, pemberian materi dilakukan dengan mengirimkan materi-materi melalui email dengan menggunakan rekaman materi-materi yang bisa disusun kemudian dikirim oleh mahasiswa dan meminta mahasiswanya untuk menganalisis, dan memperkaya bahan, sehingga tidak banyak mengandalkan media online yang bersifat saat itu diberikan saat itu juga sampai kepada khalayak.

Kepala Humas Universitas Tarumanagara mengatakan bahwa terdapat juga hambatan personal yang berasal dari komunikan dimana tidak semua khalayak internal memahami cara berkomunikasi sacara daring dan juga tidak semua khalayak internal mengikuti pengumuman yang disebarkan secara daring. Maka dari itu, untuk mengatasi hambatan ini, humas Universitas Tarumanagara bekerja sama dengan unit lain dalam melakukan pelatihan penggunaan MS. Teams dan mensosialisasikan 
kepada khalayak internal untuk selalu mengikuti informasi dan pengumuman yang diberikan melalui media daring yang dikelola oleh Humas Universitas Tarumanagara. Sedangkan Firman mengatakan bahwa bisa jadi di masa yang akan datang mungkin saja semua perkuliahan diseluruh dunia dilakukan secara daring, karena hambatan personal ini bisa saja terjadi sekarang atau nanti di masa depan, maka lebih baik jika masalah ini ditangani dari sekarang.

\section{Simpulan}

Dari hasil penelitian tentang Strategi Komunikasi Humas Universitas Tarumanagara Selama Pandemi Covid-19, maka dapat disimpulkan sebagai berikut:

1. Selama pandemi, Humas Untar menyampaikan pesan dengan menggunakan metode penyampaian pesan yang iformatif, dan pesan yang disusun juga disesuaikan dengan tergantung siapa yang menjadi khalayaknya, untuk mengetahui siapa khalayak Humas Untar membagi ke dalam dua macam khalayak, seperti khalayak internal yang terdiri dari, Dosen, karyawan dan Mahasiswa, serta khalayak eksternal yang terdiri dari Pemerintah, media, masyarakat sekitar (komunitas), alumni, dan masyarakat umum.

2. Selama pandemi, pemanfaatan media sosial Instagram, Facebook, Twitter, Youtube, WhatsApp, Line, serta aplikasi video conference seperti MS.Teams dan Zoom merupakan senjata utama yang digunakan dalam menjalankan komunikasi daring kepada sesama publik internal Universitas dan kepada khalayak eksternal Universitas. Tujuannya adalah untuk melindungi seluruh pihak internal Universitas Tarumangara dari penularan virus Covid-19.

3. Strategi komunikasi yang diterapkan oleh Humas Universitas Tarumanagara, terdapat hambatan yang menghambat pembagian pesan kepada khalayak. Hambatan yang dialami oleh humas Universitas Tarumanagara adalah hambatan teknis yang disebabkan jaringan yang tidak stabil dan hambatan personal yang disebabkan karena tidak semua khalayak internal memahami cara berkomunikasi sacara daring dan juga tidak semua khalayak internal mengikuti pengumuman yang disebarkan secara daring.

\section{Ucapan Terima Kasih}

Peneliti ingin mengucapkan terima kasih kepada Fakultas Ilmu Komunikasi Universitas Tarumanagara, narasumber, serta semua pihak yang turut membantu peneliti sehingga penelitian ini dapat diselesaikan.

\section{Daftar Pustaka}

Budianto, H. (2011). Media dan Komunikasi Politik. Jakarta. Pusat Studi Komunikasi dan Bisnis Program Pascasarjana Universitas Mercu Buana.

Effendy, Onong Uchjana. 2011. Ilmu Komunikasi Teori dan Praktek. Bandung: PT. Remaja Rosdakarya.

Estaswara. 2012. Stakeholder Relations Relations Mengelola Stakeholder Melalui Komunikasi Strategis. Jakarta: Universitas Pancasila

Mulyana, Deddy. 2010. Ilmu Komunikasi Suatu Pengantar Cet.14. Bandung: PT. Remaja Rosdakarya. 
Juhji, B. N., Arifudin, O., Mustafa, M., Choiriyati, W., Hanika, I. M., Tanjung, R., \& Adiarsi, G. R. (2020). Manajemen Humas Pada Lembaga Pendidikan (Vol. 2). Bandung: Penerbit Widina.

Liliweri, Allo. 2010. Komunikasi Serba Ada Serba Makna. Jakarta: Kencana.

Luqman, Y. (2013). Peran Dan Posisi Hubungan Masyarakat Sebagai Fungsi Manajemen Perguruan Tinggi Negeri Di Semarang. Interaksi: Jurnal Ilmu Komunikasi, 2(1), 1-10.

Moleong, Lexy. J. 2010. Metodologi Penelitian Kualitatif (XXVII). Bandung; PT. Remaja Rosdakarya.

Patilima, Hamid. 2011. Metode Penelitian Kualitatif. Bandung: ALFABET

Setyanto, Y., \& Anggarina, P. T. (2015). Humas pada Perguruan Tinggi Hubungan dengan Media pada Institusi Pendidikan. Komunikasi dan Isu Publik. Yogyakarta: ASPIKOM, Unika Widya Mandala Surabaya, Univ. Kristen Petra Surabaya, Univ. Muhammadiyah Malang, dan Penerbit Buku Litera.

Siskawati, E., \& Surya, F. (2015). Model Akuntabilitas Organisasi Non Profit pada Masjid. Jurnal Riset dan Aplikasi: Akuntansi dan Manajemen, 1(1), 29-41.

Sugiyono. 2010. Metode Penelitian Pendidikan Pendekatan Kuantitatif, kualitatif, dan $R \& D$. Bandung: Alfabeta

Sugiyono. 2016. Metode Penelitian Pendidikan Pendekatan Kuantitatif, kualitatif, dan $R \& D$. Bandung: Alfabeta

Sugiyono. 2019. Metode Penelitian Pendidikan Pendekatan Kuantitatif, kualitatif, dan $R \& D$. Bandung: Alfabeta

Tadarusman, Yusuf. 2013. Startegi Komunikasi PT. Republika Penerbit Dalam Mempromosikan Novel Islami. Jakarta: Universitas Islam Negeri Syarif Hidayatullah

Wijaya, I. S. (2015). Perencanaan Dan Strategi Komunikasi Dalam Kegiatan Pembangunan. LENTERA, 17(1). 